\title{
The Anti-Bogomil Anathemas in the Synodikon of Tsar Boril and in THE Discourse of Kosmas the Presbyter against the Bogomils*
}

\footnotetext{
$\mathrm{D}$
} uring the last decade additional light has been shed on the history of the Synodikon of the Orthodoxy in Bulgaria. It turned out that the translation made for the Synod against the Bogomils convoked by the Bulgarian Tzar Boril in 1211 has not come to us in its original version. By the end of $14^{\text {th }} \mathrm{c}$. it was edited and amended in order to be installed in a liturgical-canonical collection known as archieratikon. The book is kept in the National Library of Sofia in Palaouzov's collection under the No 289. Apart from Synodikon it contains also several liturgical services (all to be carried out by the patriarch) and the horoi of three oecumenical councils (IV, VI and VII) and of two local councils (of the council of Patriarch Mennas and Tomos Unionis), which include the main dogmas of Orthodoxy and were especially selected so as to prove the need of restoration of the veneration of icons ${ }^{1}$. The collection was meant to meet the needs of the eparchial metropolitans, who were in charge of performing the ritual of the Triumph of Orthodoxy and such type of books was quite common in Byzantium².

The work on compiling the collection was divided in two and in all probability the two groups of editors and translators worked simultaneously. The first one dealt with the Synodikon and the liturgical services. The second group translated the respective horoi. We could not be certain whether the copyist of the famous Euthymios' ieratikon pop Gerasim, who wrote the horoi was also one of the

* This article has been written under the research project financed by the National Science Centre (Poland). Decision number: DEC-2017/26/M/HS2/00335.

\footnotetext{
${ }^{1}$ Details on the content of the collection, which also contains the Greek text of the horoses and four noted Greek chants - И. Божилов, А. ТотомановА, И. Билярски, Борилов синодик. Издание и превод, София 2010, (cetera: Борилов), p. 58-62.

${ }^{2}$ Vide also A. ТотомановА, Синодик изаря Борила в сборнике Палаузова (НБКМ № 289), [in:] XXI ежегодная богословская конференция. Церковно-исторические исследования в контексте современной науки, Москва 2011, р. 165-166.
} 
translators and editors, but his participation allows us to presume that the whole book was made by the order of the prominent Bulgarian spiritual leader patriarch Euthymios.

Leaving the text of the liturgical services untouched, the first group undertook a thorough revision of the text of the Synodikon on both linguistic and content levels. As a result not only the orthography and the grammar of the text were put in line with the norms of Euthymios' Tărnovo School ${ }^{3}$ but a series of insertions and amendments to the texts were made. The Bulgarian synodkon contains 10 rubrics with personal anathemas (22a21-23a16, $\$ \$ \$ 69-78)^{4}$, which are missing in the Greek synodikon. They are introduced with Upon all the heretics: Anathema ${ }^{5}$, followed by two rubrics that repeat the beginning of general iconoclastic anathemas on 9a21-9620, $\$ \$ 20-25$. In our view almost the whole list of anathematized heresiarchs in this insertion was drawn mostly from the horoi of the $7^{\text {th }}$ and the $6^{\text {th }}$ oecumenical councils and to a lesser extent, from the horos of the $4^{\text {th }}$ Oecumenical council and of the council of Patriarch Mennas ${ }^{6}$ and does not agree with the Greek synodikon. Even more - the anathemas on Theodore of Pharan, Sergios and Pyros, Peter and Paul - patriarchs of Constantinople, Honorius - Pope of Rome, Kyros of Alexandria, Makarios of Antioch and his disciple Stephan (23a1-7) have been taken directly from the horos of the $6^{\text {th }}$ Oecumenical Council ${ }^{7}$. Only the names of Symeon Magus, Kukuvrik Manent, Eusebios, Naukratios and Jacob (five out of 30 mentioned Byzantine heresiarchs) and the respective anathemas are missing in the attached horoi and must have come from different sources.

The interrelation between the horoi and the $14^{\text {th }} \mathrm{c}$. version of Boril's synodikon could be traced in the commemorative part of the Synodikon as well. It opens with the list of Byzantine rulers that does not completely agree with the list in the Greek synodikon and begins with a praise to Constantine the Great and his mother Helena (25620-26a3, $\$ 106)$ followed by the names of Theodosios, Honorios, Theodosios II and Markianos, also missing in the Greek original. Markianos and his mother Pulcheria in their turn are praised repeatedly as a new Constantine and Helena in the attached horo $i^{8}$. The $14^{\text {th }} \mathrm{c}$. editors must have also amended the lists

\footnotetext{
${ }^{3}$ On this matter s. A. ТотомановА, Езикът на ХIV век и съставът на Палаузовия сборник, Pbg 36, 1, 2012, p. 24-37.

${ }^{4}$ The folia and the paragraphs are cited according to Борилов (София 2010).

${ }^{5}$ Here and afterwards, the fragments are quoted from the English translation by M. PAneva in Борилов, р. 337-377.

${ }^{6}$ A. Тотоманова, Синодик изаря Борила..., p. 170-171. Vide there also our polemics with I. Božilov who considers the horos of the Council of 843 published by J. Gouillard (Le Synodikon de l'Orthodoxie: édition et commentaire, TM 2, 1967, Appendice I, p. 293-298) to be the main source of this part.

${ }^{7}$ The coinciding texts - A. Тотоманова, Синодик изаря Борила..., p. 167.

${ }^{8}$ Ibidem, p. 168-199.
} 
of Bulgarian kings, queens and spiritual leaders and brought it up to their own time. They inserted also two historical accounts related to the Bulgarian history - the first one of the Synod itself (29a4-3062, $\$ \$ 110-112)$ heavily influenced by the narrative of Anna Komnena on the trial of Basil the Physician', and the second - about the re-establishment of the Bulgarian Patriarchate in 1235 under Tsar Ivan Asen II (30a3-32610, $\$ 113$ ), which is also preserved in other collections ${ }^{10}$. From this perspective the missing name of the uniate leader of the Bulgarian Church primate (archibishop) Basilios (1204-1227) could be explained as a simple damnatio memoriae.

The $14^{\text {th }} \mathrm{c}$. editors must have had at their disposal the Palaelogan version of the Greek synodikon as well because at the end of the Komnene's text that was translated for the Synod of 1211 they repeated the first three (22a14-20, $\$ \$ 66-68$ ) of the seven general anti-iconoclastic anathemas that had already been included after the anathema on Gerontios of Lampe (9a21-9620, $\$ \$ 20-25)^{11}$. In the Byzantine Synodikon these anathemas occupy lines G. 752-762 in the Greek Palaeologan version $(P)$ after the anathema on Gregory Palamas. The presumption that the editors used some Palaeologan text during their work on the Synodikon is supported by the fact that on $\mathrm{f}$. 27, the exact place of which in the book cannot be identified with certainty, although disagreeing with the text of the version $(P)$, anathemas upon Barlaam, Akindynos, Prohoros Kydones, Fudul and his teacher Piropoul (27a10-27620, $\$ \$ 176-177)$ are presented.

It has not been noticed for a long time that at the end of the negative canonical part of the Synodikon there is another insertion that contains 26 rubrics with anathemas and praises $(23 \mathrm{a} 17-25617, \$ \$ 80-104)^{12}$. Twenty of them are anathemas upon basic Bogomil beliefs and practices. As the preceding personal anathemas and the general anti-iconoclastic anathemas taken from the horos of the $7^{\text {th }}$ Oecumenical Council (vide above) this set of twenty anathemas is introduced with the exclamation: Upon all heretics: Anathema! ${ }^{13}$

\footnotetext{
${ }^{9}$ И. Божилов, Въведение в проблематиката на българския синодик, [in:] Борилов, p. 37.

${ }^{10}$ Recently A. Nikolov published a critical edition of the account about the re-establishment of the Bulgarian Patriarchate in 1235 under Tsar Ivan Asen II, based on all 4 known witnesses. Vide А. Николов, Межу Рим и Константинопол. Из антикатолическата литература в България и славянския правоставен свят (XI-XVII в.), София 2016, p. 138-141, 282-284. Vide also A. Тотоманова, Езикът на XIV век..., p. 35-36; ЕADEM, The Synodikon of Orthodoxy in Medieval Bulgaria, SCer 7, 2017, p. 174.

${ }^{11}$ The anathemas are taken from the horos of the $7^{\text {th }}$ Oecumenical Council. Vide J. Gouillard, Le Synodikon..., p. 92, note 308.

${ }^{12}$ A. Totomanova, Synodicum Bulgaricum 1211 (Critical Edition with Introduction), [in:] The Councils of the Orthodox Churches in the Byzantine and Post-Byzantine Era, ed. A. Melloni, F. LaUritzen, G. Vlantis, C. Hovorun, D. Dainese, Turnhout 2016 [= COGD, 4], p. 433; eadem, The Synodikon of Orthodoxy..., p. 173.

${ }^{13} \mathrm{Cf}$. the Old Bulgarian text in the left column of table 2.
} 
The first 4 anathemas (23a18-23616, $\$ \$ 80-83)$ condemn those who do not believe in the Holy Trinity, deny the equality of its substances and add to it a fourth member, called "consoler".

The ensuing 3 anathemas (23611-18, $\$ \$ 84-86)$ reprove the rejection of the divine incarnation and the resurrection of Christ in flesh as well as the disrespect towards the Holy Virgin.

The anathema on 23619-24a1, $\$ 87$ blames those who do not believe in the Parousia of Christ and the Last Judgement.

The anathema on $24 \mathrm{a} 2-5, \S 88$ curses those who do not accept God's Law (i.e. Old and New Testament) and it is thematically connected with the anathema on 24a20-2462, $\$ 94$ upon those who do not trust the prophets and first of all John the Baptist.

The anathema on $24 \mathrm{a} 13-15, \S 91$ blames those who do not believe that God accepts a man repenting of his sins.

The following 2 anathemas (24a16-19, $\$ \$ 92-93)$ rebuke the dualistic belief that the devil is the master of the world and the Lord did not create both heaven and earth.

The last 6 anathemas refer to:

- the wrong views on the Eucharist, according to which the wine and bread are not the blood and the flesh of Christ (2463-5, § 95);

- docetistic attitudes of the heretics who do not venerate the sacred relics and the holy and life-giving cross (2466-14, \$\$ 96-97);

- the disrespect to the holy churches that are considered mere temples and are being ruined by the heretics together with bishoprics and monasteries (24615-25a8, \$\$ 98-99);

- those who dedicate themselves to sorcery, charming and any kind of witchcraft and divinations (25a20-2568, $\$ \$ 101-102)$.

This part of the Synodikon contains three praises and two anathemas that at first glance seem to interrupt the logics of the anti-Bogomil anathemas. The first praise Those who have come back from any heresy to the Orthodox faith and adhere to it with all their souls: May their memory be eternal! (24a6-9, \$ 89) however contradicts the rejection of the repentance and the refusal of abjuration in Bogomils' practices, which comes from their belief that God does not accept a man repenting from his sins $(24 \mathrm{a} 13-15, \S 91)$. It is thematically related to the second and the third praises that are for those who hold the Orthodox faith according to the Gospels (25a9-19, \$100) and for all boyars, priests and monks and all the people who piously keep their devotion to the king and to the archbishops pure and 
righteous (2569-14, $\$ 103$ ). On the other hand the first praise is related to another praise in the positive canonical part of the Synodikon on 565-8: All who came to our Orthodox faith from the unholy Armenian faith: May their memory be eternal! This eternal memory is repeated almost literally on 5620-22: All who accepted Orthodox Christian faith: May their memory be eternal! and bridges the positive and the negative canonical parts. Therefore eternal memory for all who repented of the heresies logically introduces the anathema against the Armenian heresy. The interrelations between these rubrics are so obvious to make us think that the two exclamations in the positive part in the Synodikon are also inserted by the $14^{\text {th }} \mathrm{c}$. editors. Only the anathema, which condemns all the thieves, murderers and robbers somehow falls out from the anti-Bogomil and anti-heretical thematic. Yet on the f. 27a1-8 ( $\$ 175)$ whose place in the codex is impossible to identify before the anathemas upon Akindynos and Barlaam a similar anathema is to be found: Upon all who pillage the homes of the Christians and steal horses or oxen or rob in the roads to damage and harm the Christians and on all who order such evil deeds or know about them but attempt to hush the affair: Anathema!

Despite the incongruences in this part it is clear that the Bulgarian men of letters who edited and amended the $13^{\text {th }} \mathrm{c}$. translation of the Synodikon were familiar with a compendium of anti-Bogomil and anti-heretical texts and included them in the $14^{\text {th }} \mathrm{c}$. version of the Synodikon. On the other hand the incongruences might indicate the different layers of editorial intervention: the first one used the antiheretical texts that are scattered in different types of collections, the second one introduced the actual problems of the Bulgarian society at the turn of the $14^{\text {th }}$ and the $15^{\text {th }} \mathrm{cc}$. - the spread of different types of heresies and crimes against ordinary people. The inclusion of the names of $14^{\text {th }} \mathrm{c}$. heretics and of the anathemas upon robbers and the thieves and those helping and covering them supports such an assumption. From this prospective the praises for those who keep the Christian values and obey to the rulers and laws are more than founded.

The $14^{\text {th }} \mathrm{c}$. editors carried on the tradition of their predecessors (editors and compilers of the beginning of the $13^{\text {th }} \mathrm{c}$.) who replaced the anti-Bogomil anathemas from the Constantinople version of Synodikon (G. 250-387) with the anathemas taken from the Letter of Patriarch Kosmas ${ }^{14}$ to the dearest metropolitan of Larisa in connection with the ungodly heretics ${ }^{15}(1366-15619, \$ \$ 39-52)$. The text of Kosmas was re-arranged: the first three anathemas (13612-14a12, $\$ \$ 39-41$ / actually No 9, 10, 11 in Kosmas' letter) after the introduction condemn the heresiarch Bogomil and his docetistic concept that Jesus Christ had no human body and he only appears to have died on the cross together with those who dedicate

\footnotetext{
${ }^{14}$ It might be Kosmas I, 1075-1081 or Kosmas II Atticos, 1146-1147.

${ }^{15}$ The text of the letter is preserved in Marcianus gr. II 74 (Coll. 1454 olim Nanianus 96), ff. $77^{\mathrm{v}}-79^{\mathrm{v}}$ of the $15^{\text {th }}$ c., cf. J. Gouillard, Une source grecque du Synodik de Boril: la lettre du patriarche Cosmas, TM 4, 1970, p. 361-374.
} 
themselves to the rites of the new heresy and those who communicate with any of these heretics (No 4, 1, 2 in Kosmas' letter). The next anathema (14a13-19, $₫ 42$ / No 3 in Kosmas' letter) reproves those involved in the mysteries similar to the pagan rites on the eve of the John the Baptist birthday.

The ensuing nine anathemas refer to Bogomils' basic beliefs such as:

- the dualistic concept that the Satan is the creator of the visible world and of Adam and Eve (14a20-1465, $\$ \$ 43-44$ / No 1, 2 in Kosmas' letter);

- the rejection of the Mosaic Law and of the Old Testaments in general (1466-19, $\$ 45$ / No 3);

- the rejection of the baptism was tackled upon by two anathemas (14620-15a13, $\$ \$ 46-47$ / No 4) of which the first one is missing in Patriarch Kosmas' letter but serves as an introduction to the second one that rebukes those who calumniate John the Baptist and baptize without water just saying Pater noster (15a7-13, $\S 47)$;

- the rejection of the church services (15a14-19, $\$ 48 /$ No 5) and the holy liturgy (15a20-1563, § 49 / No 6);

- the rejection of the Eucharist (15a20-1563, §50 / No 7);

- the refusal to venerate the holy cross (15611-14, $\$ 51 /$ No 8).

The last anathema taken from the letter of the Patriarch Kosmas (15615-19, $\$ 52$ / No 12) casts the blame on those who accept Bogomils in the holy church before they have performed the rite of abjuration ${ }^{16}$. The next anathema refers to Basil the Physician who introduced the Bogomil heresy in Constantinople under the Orthodox Emperor Alexius Comnenus $(16 \mathrm{a} 4-1665, \$ 53)$ and it is thematically related to the Bogomil movement.

The comparison between the two sets of anathemas shows that the anathemas, included at the end of the canonical part of the Synodikon, generally repeat the 12 anti-Bogomil anathemas from the letter of the Patriarch Kosmas but in a simpler language, more understandable to the faithful. On the other hand, their content and simple wording strongly reminds the anathemas we find in the chapter "On the faith" of the Discourse of Kosmas the Presbyter against the Bogomils. The anathemas there refer to ${ }^{17}$ :

\footnotetext{
${ }^{16}$ The $12^{\text {th }} \mathrm{c}$. formulas of abjuration and confession for Bogomils are studied and published by P. Eleuteri, A. Rigo, Eretici, dissident, musulmani ed ebrei a Bysanzio, Venezia 1993, p. 125-134, 153-155. We are convinced that Upon those who accept any of these heretics in Gods holy church, before they've confessed and cursed the whole heresy, as it has been said: Anathema! refers to the described rituals.

${ }^{17}$ Vide table 2. The text of the Discourse against the Bogomils is cited according to the edition of Ю. Бегунов, Козма Презвитер в славянских литературах, София 1973.
} 
- all who are not true Christians (condemns all who do not love Christ),

- the twisted concepts of the Holy Trinity,

- the wrong views on the Eucharist,

- the disrespect to the Holy Virgin,

- the refusal to venerate the holy cross,

- iconoclastic attitudes,

- the rejection of the New Testament,

- the rejection of the prophetic predictions,

- the refusal to worship the relics of saints,

- the rejection of the liturgical services and prayers,

- the dualistic concept that God did not create the visible word,

- the twisted New Testament,

- the rejection of the Mosaic Law,

- disrespect to the church hierarchy, established by the Lord and the Apostles (No 14, 15),

- the rejection of marriage,

- the blames on those who eat meat and drink wine according to the Law.

The anti-Bogomil anathemas of the Discourse were extracted and included in two anti-heretical compilations: a Bulgarian Compilation against the Bogomil Theodor of Sicily and a Russian Compilation made by the Metropolitan of Kiev Georgij the Greek installed in The Commandments of the Holy Fathers to the confessing sons and daughters. According to Begunov's opinion the anathemas in the Commandments were not borrowed directly from the Discourse and its compiler Georgij the Greek used the Bulgarian compilation as a text mediator. The Bulgarian compilation is preserved in the Nomocanon of Ustjug (beginning of the $14^{\text {th }} \mathrm{c}$.) and in the so called Joasaph's Nomocanon (beginning of the $16^{\text {th }} \mathrm{c}$. ${ }^{18}$. The latter proves the high prestige of these anathemas and ensures their dissemination all over the Orthodox Slavonic world. Both compilations are critically edited and published by Begunov ${ }^{19}$. In our opinion the $14^{\text {th }} \mathrm{c}$. editors of the Bulgarian Synodikon must have been familiar with a compilation of this type.

The table 1 below displays all Bogomil topics tackled upon in the tree sets of anathemas and confirms the thematic connection between them:

\footnotetext{
${ }^{18}$ Ibidem, p. 28-33.

${ }^{19}$ Ibidem, p. 393-399.
} 
Table 1

Thematic connections between $\$ \$ 80-104$ of Bulgarian Synodikon and Discourse of Kosmas the Presbyter and Letter of Patriarch Kosmas in $\$ \$ 39-52$ of Bulgarian Synodikon

\begin{tabular}{|c|c|c|}
\hline P 23a17-25б17, $\$ \$ 80-104$ & Kosmas the Presbyter & $\begin{array}{c}\text { Patriarch Kosmas } \\
\text { in P 1366-15619, } \$ \$ 39-52\end{array}$ \\
\hline $\begin{array}{l}\$ 79 \\
\text { all heretics }\end{array}$ & $\mathbf{1}$ all heretics and pagans & $\begin{array}{l}\$ \$ 39-40 \\
\text { Bogomils }\end{array}$ \\
\hline SS 80-83 & $\begin{array}{l}2 \text { the twisted concepts of } \\
\text { the Holy Trinity }\end{array}$ & \\
\hline$\$ 96$ & $\begin{array}{l}3 \text { the wrong views on } \\
\text { the Eucharist }\end{array}$ & \\
\hline \multirow[t]{2}{*}{$\$ 85$} & $\begin{array}{l}4 \text { the disrespect to } \\
\text { the Holy Virgin }\end{array}$ & \\
\hline & & $\begin{array}{l}\$ \$ 46-47 \\
\text { refusal of baptism }\end{array}$ \\
\hline SS 84-86 & & $\begin{array}{l}\$ \$ 40-41 \text { no Divine Incar- } \\
\text { nation and resurrection }\end{array}$ \\
\hline \multicolumn{3}{|l|}{$\begin{array}{l}\$ 87 \\
\text { no Parousia of Christ and } \\
\text { Last Judgement }\end{array}$} \\
\hline$\$ 97$ & $\begin{array}{l}5 \text { the refusal to venerate } \\
\text { the holy cross }\end{array}$ & $\$ 51$ \\
\hline \multirow[t]{2}{*}{$\$ 91$} & & $\begin{array}{l}\$ 52 \\
\text { no repentance }\end{array}$ \\
\hline & 6 iconoclastic attitudes & \\
\hline$\$ 88$ & $\begin{array}{l}7 \text { the rejection of the } \\
\text { New Testament }\end{array}$ & \\
\hline$\$ 94$ & $\begin{array}{l}8 \text { the rejection of the } \\
\text { prophetic predictions }\end{array}$ & \\
\hline
\end{tabular}




\begin{tabular}{|c|c|c|}
\hline P 23a17-25б17, $\$ \$ 80-104$ & Kosmas the Presbyter & $\begin{array}{c}\text { Patriarch Kosmas } \\
\text { in P 1366-15619, } \$ \$ 39-52\end{array}$ \\
\hline$\$ 97$ & $\begin{array}{l}9 \text { the refusal to worship } \\
\text { the relics of saints }\end{array}$ & \\
\hline$\$ 97$ & $\begin{array}{l}10 \text { the rejection of } \\
\text { the liturgical services } \\
\text { and prayers }\end{array}$ & SS 48-49 \\
\hline SS 92-93 & $\begin{array}{l}11 \text { the dualistic concept } \\
\text { that God did not create } \\
\text { the visible word }\end{array}$ & $S \$ 43-44$ \\
\hline$\$ 88$ & $\begin{array}{l}12 \text { the twisted New } \\
\text { Testament }\end{array}$ & \\
\hline \multirow[t]{4}{*}{$\$ 88$} & $\begin{array}{l}13 \text { the rejection of } \\
\text { the Mosaic law }\end{array}$ & $\$ 45$ \\
\hline & $\begin{array}{l}\text { 14-15 disrespect to the } \\
\text { church hierarchy, estab- } \\
\text { lished by the Lord and } \\
\text { the Apostles }\end{array}$ & \\
\hline & $\begin{array}{l}16 \text { the rejection of } \\
\text { marriage }\end{array}$ & \\
\hline & $\begin{array}{l}17 \text { the blames on those } \\
\text { who eat meat and drink } \\
\text { wine according to the Law }\end{array}$ & \\
\hline \multicolumn{3}{|l|}{$\begin{array}{l}\text { SS } 98-99 \\
\text { the disrespect to the holy } \\
\text { churches, bishoprics and } \\
\text { monasteries }\end{array}$} \\
\hline $\begin{array}{l}\text { SS 101-102 } \\
\text { against sorcery, charming } \\
\text { and any kind of witch- } \\
\text { craft and divinations }\end{array}$ & & $\$ \$ 40-42$ \\
\hline
\end{tabular}

As one may see the anathemas at the end of the Synodikon refer to most Bogomil beliefs and practices condemned by Kosmas the Presbyter except the iconoclastic attitudes, which are ascribed to all heretics in general post-iconoclastic period ${ }^{20}$,

\footnotetext{
${ }^{20}$ A. Rigo, L'Assemblea generale atonita del 1344 su un gruppo di monaci bogomili (ms. Vat.Gr. 604 ff. $11 r-12 v$ ), CS 5, 1984, p. 486-487; IDEM, Monaci esicasti e monaci bogomili. Le accuse di messalianismo
} 
the rejection of marriage, meat and wine according to the Christian Law. The disrespect to the holy churches, bishoprics and monasteries is connected to the disrespect to the church hierarchy. In addition there are some topics in common with the Letter of Patriarch Kosmas: the Bogomils' attitude to the Divine Incarnation and Resurrection, the repentance and its consequences, witchcraft, sorcery and pagan rites in Bogomils' communities. Only here we find information that Bogomils do not believe in the Parousia of Christ and the Last Judgment.

Table 2

\section{Comparison between anathemas from $\$ \$ 80-104$ of Bulgarian Synodikon and anathemas from Discourse of Kosmas the Presbyter}

\begin{tabular}{|c|c|c|c|}
\hline $\begin{array}{c}\text { Synodikon 23a17-25б17, } \\
\qquad \$ 80-104\end{array}$ & & Kosmas the Presbyter & \\
\hline 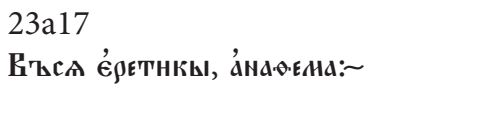 & 79 & 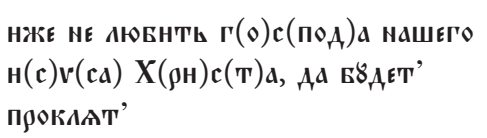 & 1 \\
\hline 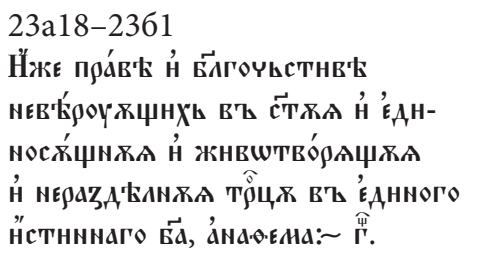 & 80 & \multirow[t]{4}{*}{ 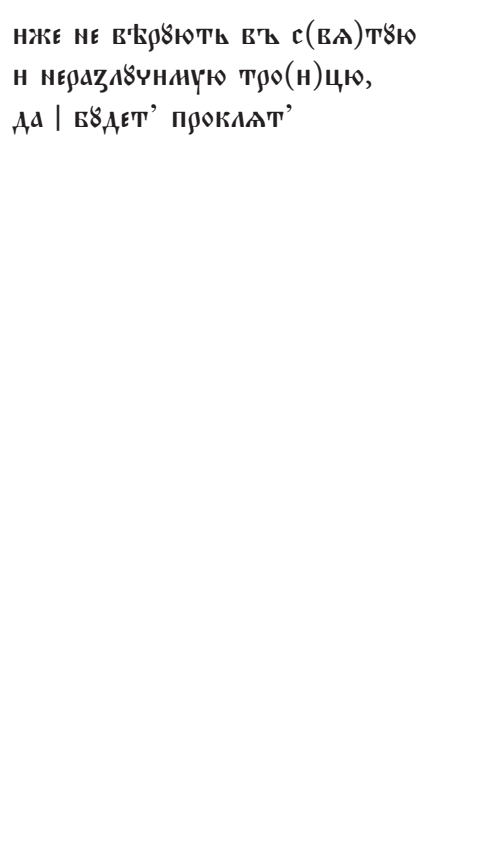 } & \multirow[t]{4}{*}{2} \\
\hline 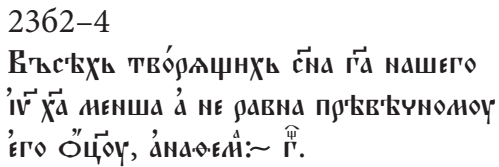 & 81 & & \\
\hline 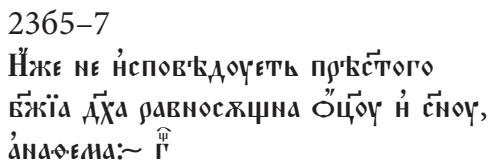 & 82 & & \\
\hline 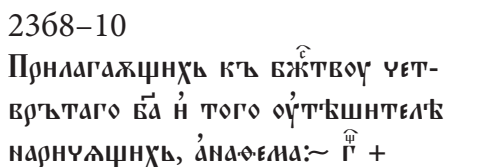 & 83 & & \\
\hline
\end{tabular}

e bogomilismo rivolte agli esicasti ed il problema dei rapporti tra esicasmo e bogomilismo, Firenze 1989 [= OV, 2], p. 198-200, 248-254. 


\begin{tabular}{|c|c|c|c|}
\hline $\begin{array}{c}\text { Synodikon 23a17-25б17, } \\
\qquad \$ 80-104\end{array}$ & & Kosmas the Presbyter & \\
\hline 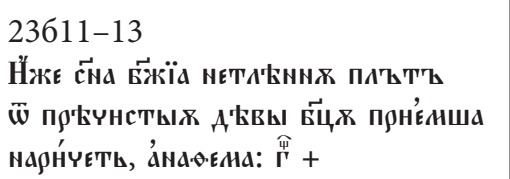 & 84 & 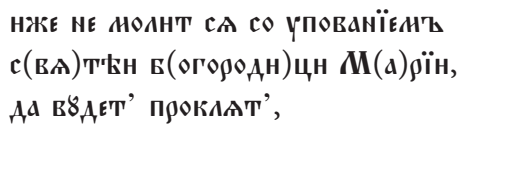 & 4 \\
\hline 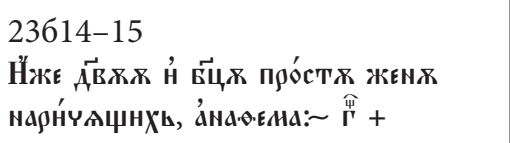 & 85 & & \\
\hline 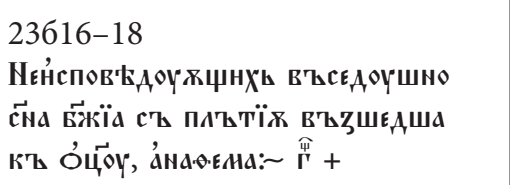 & 86 & & \\
\hline 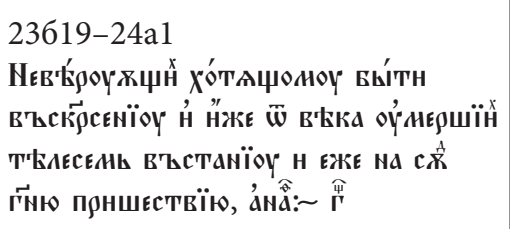 & 87 & & \\
\hline 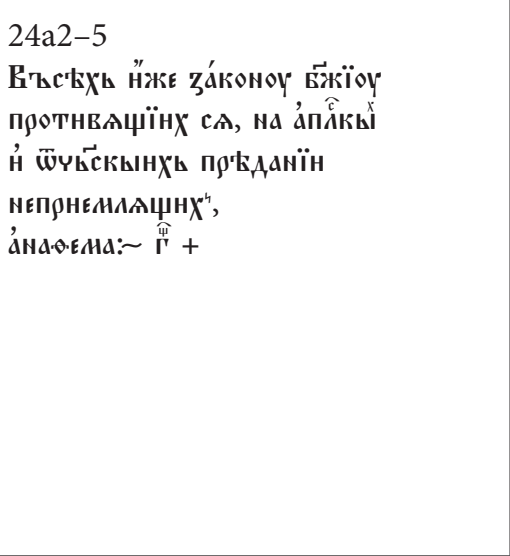 & 88 & 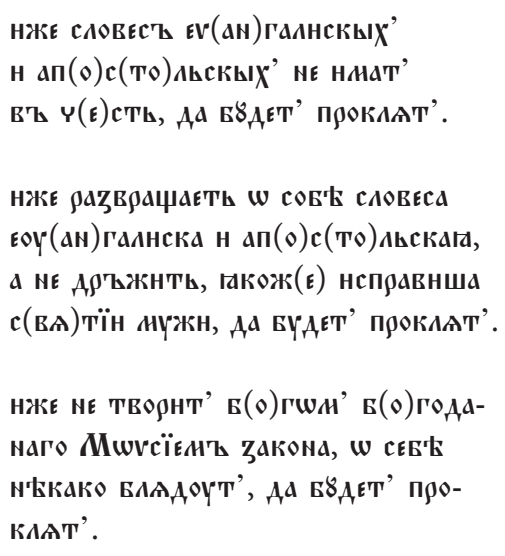 & $\begin{array}{r}7 \\
12\end{array}$ \\
\hline 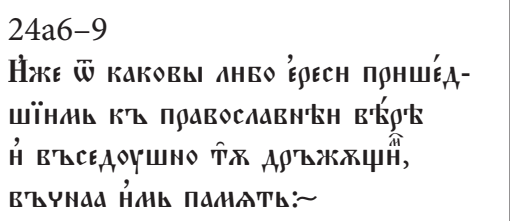 & 89 & & \\
\hline
\end{tabular}




\begin{tabular}{|c|c|c|c|}
\hline $\begin{array}{c}\text { Synodikon 23a17-25б17, } \\
\qquad \$ 80-104\end{array}$ & & Kosmas the Presbyter & \\
\hline 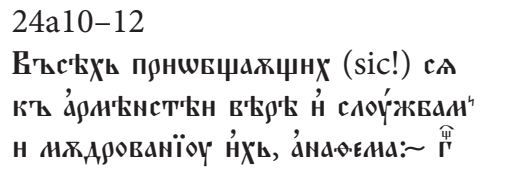 & 90 & & \\
\hline 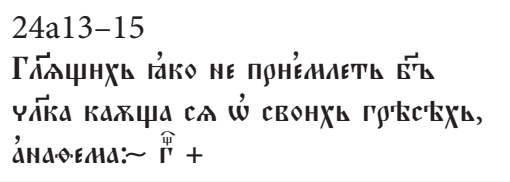 & 91 & & \\
\hline 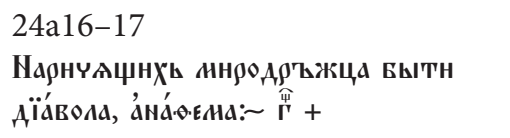 & 92 & \multirow{2}{*}{ 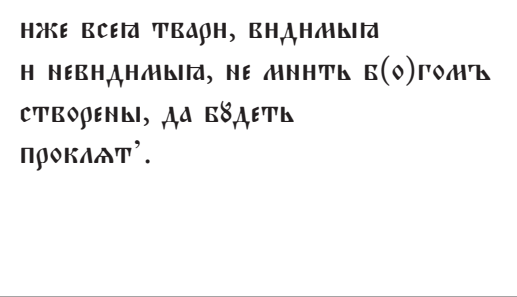 } & \multirow[t]{2}{*}{11} \\
\hline 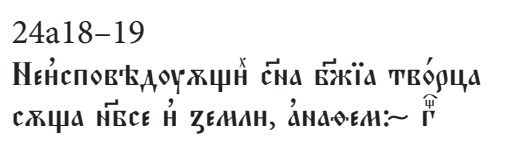 & 93 & & \\
\hline 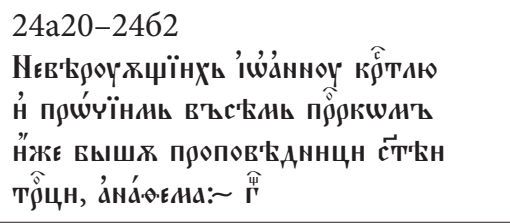 & 94 & 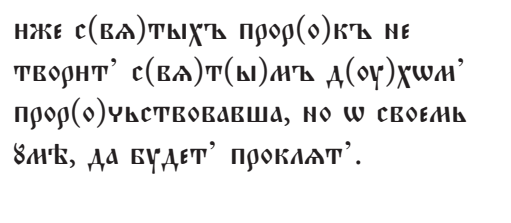 & 8 \\
\hline 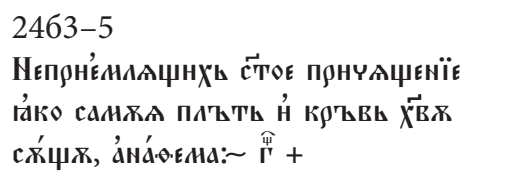 & 95 & 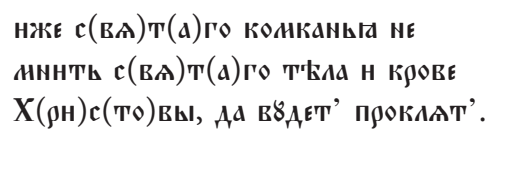 & 3 \\
\hline 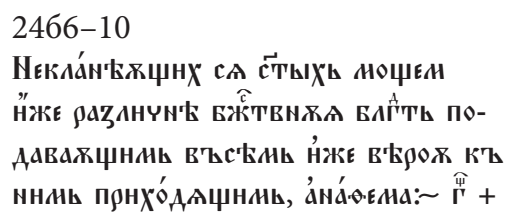 & 96 & 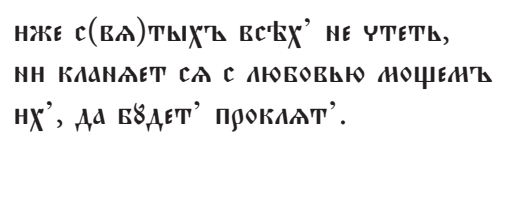 & 9 \\
\hline 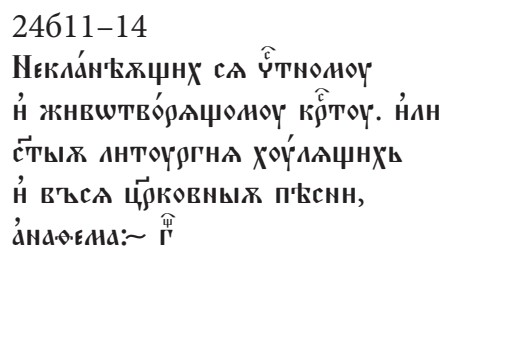 & 97 & 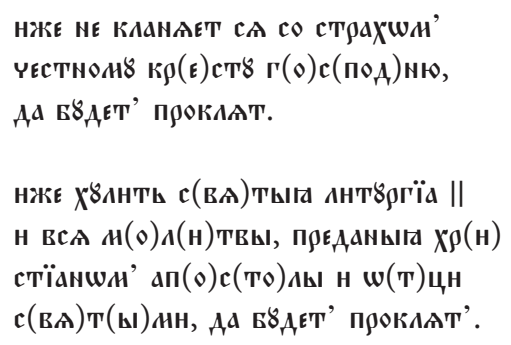 & 10 \\
\hline
\end{tabular}




\begin{tabular}{|c|c|c|c|}
\hline $\begin{array}{c}\text { Synodikon 23a17-25б17, } \\
\$ \$ 80-104\end{array}$ & & Kosmas the Presbyter & \\
\hline 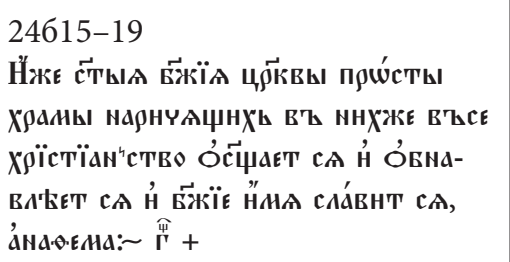 & 98 & 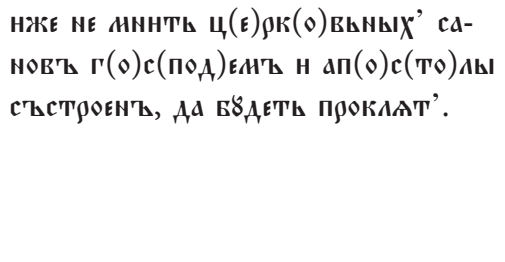 & 14 \\
\hline 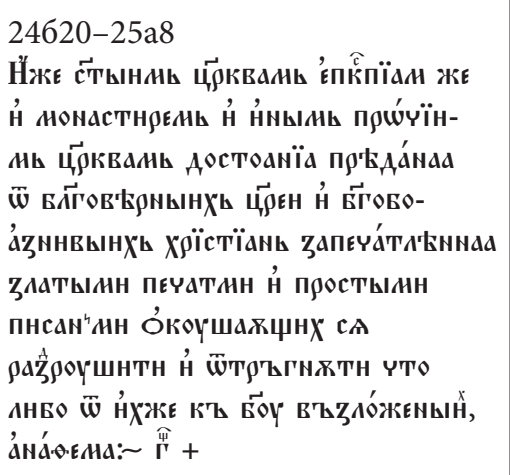 & 99 & 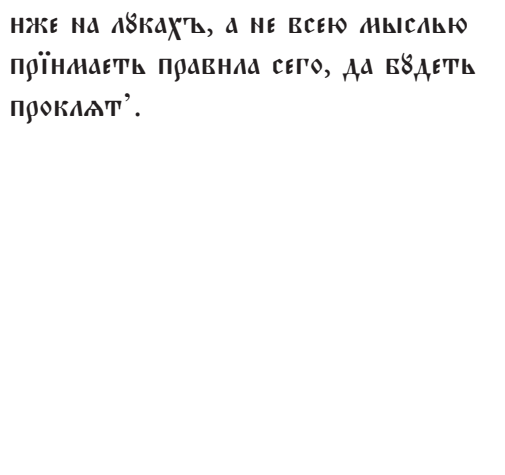 & 15 \\
\hline 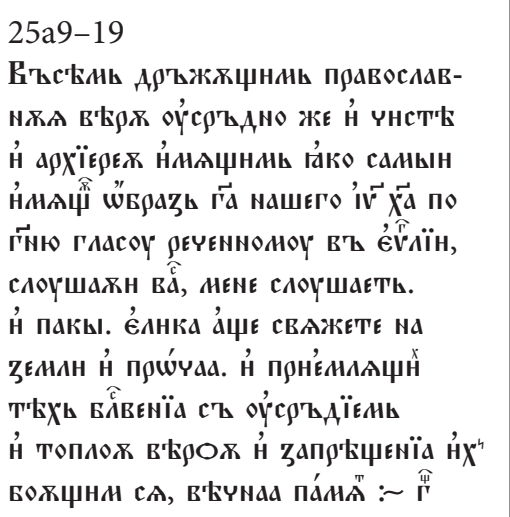 & 100 & & \\
\hline 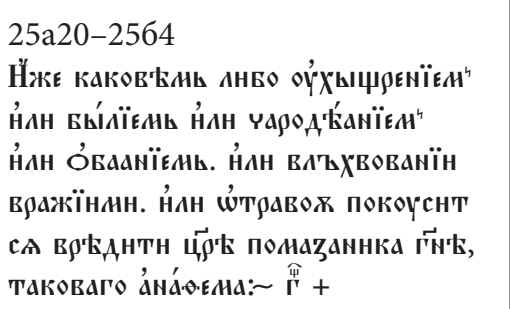 & 101 & & \\
\hline
\end{tabular}




\begin{tabular}{|c|c|c|}
\hline $\begin{array}{c}\text { Synodikon 23a17-25б17, } \\
\qquad \$ 80-104\end{array}$ & & Kosmas the Presbyter \\
\hline 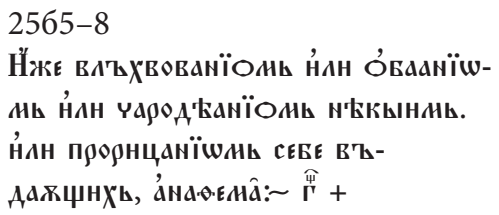 & 102 & \\
\hline 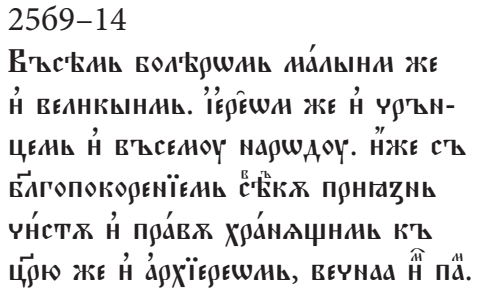 & 103 & \\
\hline 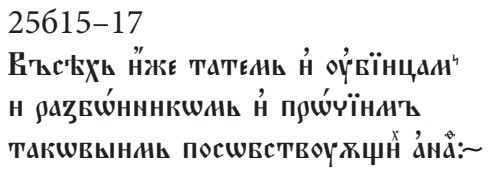 & 104 & \\
\hline 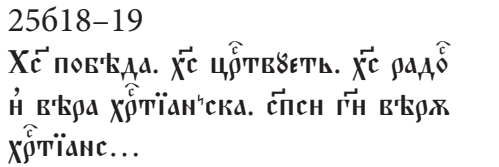 & 105 & \\
\hline
\end{tabular}

The editors seem to have summarized here at the end of the canonical part of the Synodikon all they reproved of Bogomils' behavior and theology and placed it before the exclamation: Christ is victory, Christ rules, Christ is the joy of Christian faith. God save Christian faith! The exclamation strongly reminds of the refrain of laudes regiae "Christus vincit, Christus regnat, Christus imperat" and comes from the Byzantine ceremonial being a shortened version of the exclamations given by Sards to the emperors that are included by Constantine Porphyrogenitus in chapter 43 of $\mathrm{De} \mathrm{Cerimoniis}^{21}$. Is the fact that the canonical part of the Bulgarian Synodikon ends with an exclamation related to the history of Bulgarian lands and especially to the region of Serdica / Sardica just a mere coincidence? Could it be that the exclamation is a reminiscence of the anti-Arian council convened in the city of Serdica between 340 and $347^{22}$ ? Given the fact that Matej

${ }^{21}$ Vide Corpus scriptorum historiae Byzantinae, vol. 16-17: Constantini Porphyrogeniti Imperatoris. De cerimoniis aulae Byzantinae libri duo, vol. I-II, ed. J.J. ReIske, Bonnae 1829-1830, p. 650-651.

${ }^{22}$ On the date and the statute of this council - В. ВАчковА, Сердикийският събор: 1670 години история и интерпретащии, София 2013. 
Gramatik who wrote the Vita of Saint Nikola Novi of Sofia in $16^{\text {th }}$ c. refers to the city as to the great city of Sardica called Sredec ${ }^{23}$, that is a plausible hypothesis. But we do not know for sure. What we certainly know is that the Bulgarian part of the $14^{\text {th }} \mathrm{c}$. version of the Synodikon together with the diptychs and historical accounts was included into the so called Drinov copy of Synodikon (MS No 432 in the National Library). The first canonical part of the Synodikon in this codex is replaced with a different $14^{\text {th }} \mathrm{c}$. translation of the Palaeologan version of the Greek Synodikon ${ }^{24}$. The question why Patriarch Euthymius did not order such a translation remains still unanswered.

\section{Bibliography}

Begunov Ju., Kozma Prezviter v slavjanskich literaturach, Sofija 1973.

Biljarski I., Paleologovijat sinodik v slavjanski prevod, Sofija 2013.

Božilov I., Totomanova A., Biljarski I., Borilov sinodik. Izdanie i prevod, Sofija 2010.

Constantini Porphyrogeniti Imperatoris. De cerimoniis aulae Byzantinae libri duo, vol. I-II, ed. J.J. ReIske, Bonnae 1829-1830 [= Corpus scriptorum historiae byzantinae, 16-17].

Eleuteri P., Rigo A., Eretici, dissident, musulmani ed ebrei a Bysanzio, Venezia 1993.

Gouillard J., Une source grecque du Synodik de Boril: la lettre du patriarche Cosmas, "Travaux et mémoires du Centre de recherches d'histoire et civilisation byzantines” 4, 1970, p. 361-374.

Goulllard J., Le Synodikon de l'Orthodoxie: édition et commentaire, “Travaux et mémoires du Centre de recherches d'histoire et civilisation byzantines” 2, 1967, p. 1-316.

Nikolov A., Meždu Rim i Konstantinopol. Iz antikatoličeskata literatura v Bălgarija i slavjanskija pravoslaven svjat (XI-XVII v.), Sofija 2016.

Rigo A., L'Assemblea generale atonita del 1344 su un gruppo di monaci bogomili (ms. Vat.Gr. 604 ff. 11r-12v), "Cristianesimo nella Storia. Ricerche storiche, esegetiche, teologiche" 5, 1984, p. $475-506$.

Rigo A., Monaci esicasti e monaci bogomili. Le accuse di messalianismo e bogomilismo rivolte agli esicasti ed il problema dei rapporti tra esicasmo e bogomilismo, Firenze 1989 [= Orientalia Venetiana, 2].

Tотомаnova A., Ezikăt na XIV vek i săstavăt na Palauzovija sbornik, "Palaeobulgarica / Старобългаристика" 36, 1, 2012, p. 24-37.

Totomanova A., Sinodik carja Borila v sbornike Palauzova (NBKM № 289), [in:] XXI ežegodnaja bogoslovskaja konferencija. Cerkovno-istoričeskie issledovanija v kontekste sovremennoj nauki, Moskva 2011, p. 165-171.

${ }^{23}$ Ibidem, p. 128-130.

${ }^{24}$ A. Tотомanova, The Synodikon of Orthodoxy..., p. 174-177. The Slavonic translation of the Palaeologan version of the Synodikon is preserved also in a South-Slavonic compilation, kept in Romania BAR MS. SL. 307. The publication and analysis of the text - И. Билярски, Палеологовият синодик в славянски превод, София 2013. 
Totomanova A., Synodicum Bulgaricum 1211 (Critical Edition with Introduction), [in:] The Councils of the Orthodox Churches in the Byzantine and Post-Byzantine Era, ed. A. Melloni, F. Lauritzen, G. Vlantis, C. Hovorun, D. Dainese, Turnhout 2016 [= Conciliorum Oecumenicorum Generaliumque Decreta, 4], p. 426-468.

Toтomanova A., The Synodikon of Orthodoxy in Medieval Bulgaria, "Studia Ceranea. Journal of the Waldemar Ceran Research Center for the History and Culture of the Mediterranean Area and South-Eastern Europe" 7, 2017, p. 169-227.

VAČKova V., Serdikijskijat săbor: 1670 godini istorija i interpretacii, Sofija 2013.

\begin{abstract}
During the last decade the history of the Synodikon of the Orthodoxy in Medieval Bulgaria has been tackled upon from different points of view. The author of this paper provided substantial evidence proving that the Synodikon of Tsar Boril did not survive in its original form. By the end of the $14^{\text {th }} \mathrm{c}$. the original translation was amended and edited in order to be installed in a canonical-liturgical compilation (archieratikon) that includes texts and services related to the Feast of Orthodoxy. The compilation is kept in the National Library in Palauzov's collection No 289. Additional information about the different sources of some rubrics of the Synodikon, which do not correspond to its Greek version, was also provided. Recently we have discovered that the text, preserved in a collection of Damasckin type from the beginning of $16^{\text {th }} \mathrm{c}$. (Drinov's copy) represents indeed a compilation: its first part (the canonical one) contains the translation of the Palaeologan version of the Synodikon, which survived also in a triodion from the Library of the Romanian Academy of Sciences. The second part of the compilation however coincides with the text of the Synodikon of Tsar Boril with all amendments related to the Bulgarian history - rulers, patriarchs, bishops and nobles. This "Bulgarian" part of the Synodikon includes a series of anathemas against Bogomils, that do not have Greek correspondences and generally repeat the anti-Bogomils anathemas taken from the Letter of Patriarch Kosmas in a simpler language more understandable to the faithful. This paper is tracing the connection between these anathemas and the Anti-Bogomils anathemas in the Discourse of Kosmas the Presbyter against the Bogomils.
\end{abstract}

Keywords: Synodikon of Tsar Boril, anti-Bogomils anathemas, Kosmas the Presbyter

Anna-Maria Totomanova

Sofia University

Faculty of Slavic Studies

Department of Cyrill and Methodius Studies

15 Tsar Osvoboditel blvd.

1540 Sofia, Bulgaria

atotomanova@slav.uni-sofia.bg 